International Journal of Instruction e-ISSN: 1308-1470 • www.e-iji.net

Article submission code: 20201027071406

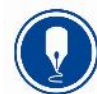

October $2021 \bullet$ Vol.14, No.4

p-ISSN: 1694-609X

pp. $549-566$

Received: 27/10/2020

Revision: 03/04/2021
Accepted: 26/04/2021

OnlineFirst: 11/08/2021

\title{
Promoting Problem-Solving Skills among Secondary Science Students through Problem Based Learning
}

\section{Adewale Magaji}

Dr, Faculty of Education, Health and Human Sciences, and Institute for Lifecourse Development (ILD)- centre for Thinking and Learning, University of Greenwich, London, UK, A.Magaji@gre.ac.uk

This research was informed by a constructivist approach to learning, with a focus on answering the research question: what skills can science teachers promote and encourage among students through designing and implementing problem-based learning in their classrooms? The research was carried out in a co-education secondary school in England and involved fifty-two Key Stage 3 students (second year of secondary education), aged 13 years old. It utilized a theoretical framework of the $3 \mathrm{C} 3 \mathrm{R}$ model $(3 \mathrm{C}$ - content, context, and connection, and 3R- researching, reasoning, and reflecting) in problem-based learning (PBL). Data were collected through lesson observations, interviews, and focus groups. It was analyzed using thematic analysis and the recurrent themes were coded by creating relationships and links to the problem-solving skills promoted by PBL. The study found that the application of prior knowledge, collaborative learning, modeling and eliciting feedback were the skills promoted by PBL and these are valuable in problemsolving. However, collaborative learning was the dominant skill promoted by PBL. Teachers' pedagogical knowledge and the time students spent researching were limiting factors in promoting problem-based learning, thereby suggesting the need for continuing professional development for teachers and further integration of blended PBL to maximize learning time.

Keywords: problem based learning, collaborative learning, eliciting feedback, constructivist, critical thinking

\section{INTRODUCTION}

Engaging students in science lessons may require pedagogical knowledge to implement various strategies such as problem-based learning. Both teachers and students may benefit from problem-based learning (PBL) as teachers need to evaluate students' learning and adjust, whilst the students are engaged in self-directed learning, solving problems, and responding to the teachers' feedback. However, an interplay of various factors influencing the success of a PBL is valuable in this process and teachers should be aware of any resulting skills and how to effectively utilize them in promoting problem-solving. For example, PBL promotes problem-solving by improving critical

Citation: Magaji, A. (2021). Promoting problem-solving skills among secondary science students through problem based learning. International Journal of Instruction, 14(4), 549-566. https://doi.org/10.29333/iji.2021.14432a 
thinking skills (Yew \& Goh, 2016; Nurkhin et al., 2020), applying prior and new knowledge, collaboration skills (Major \& Mulvihill, 2018), and thereby facilitating feedback processes by promoting a deeper understanding of scientific phenomena.

It can be argued that applying prior knowledge, collaborative learning, and eliciting feedback are vital problem-solving skills that enable feedback processes among peers. It allows teachers to assess progress and close gaps in students' knowledge. However, teachers' support in modeling feedback processes through facilitating a collaborative learning opportunity (Mustofa \& Hidayah, 2020) is important in problem-solving as it enables students to apply prior knowledge. In the same vein, designing and implementing PBL also improves teachers' pedagogical content knowledge (Vasconcelos 2012) and enables them to promote problem-solving skills such as collaboration, applying prior knowledge, and eliciting feedback processes among students. These problem-solving skills are essential to students in this $21^{\text {st }}$-century education (Munawaroh, 2020) and therefore it is necessary to highlight them and consider ways that they can be applied in the science classroom.

PBL is sparingly implemented by secondary school teachers (Merritt et al., 2017) especially in science as the focus has been on academic attainment rather than those problem-solving skills that led to the attainment. Probable reasons for not adopting PBL could include a lack of good management, teachers' pedagogical knowledge, the means to carry it out, and time involved in planning a PBL. Also, it can be confusing for some students to understand the process (Ghufron \& Ermawati, 2018). This contrasts with Ertmer \& Simons (2006) who suggest challenges ranging from creating a culture of collaboration and interdependence to scaffolding students' learning. Therefore, poorly planned PBL problems may affect the content coverage and activities required to promote the problem-solving skills mentioned earlier. However, in the context of this study, the 3C3R model of PBL (Hung, 2009) is deemed suitable in promoting those problem-solving skills among students. The $3 \mathrm{C} 3 \mathrm{R}$ is a framework implemented through 9 steps design process. The $3 \mathrm{C}$ represents the core components responsible for developing content knowledge, contextualizing domain knowledge, and building a conceptual framework while the $3 \mathrm{R}$ represents the processing components such as researching, reasoning, and reflecting. This framework enhances self-directed learning enabling collaboration, applying prior knowledge, modeling and eliciting feedback during problem-solving. This study will answer the research question: what problemsolving skills can science teachers promote and encourage among science students through designing and implementing PBL in their classrooms?

\section{Theoretically framing the literature on PBL}

PBL is an effective instructional approach in promoting problem-solving and teachers must understand those mechanisms that constitute how it works (Yew \& Goh, 2016). PBL facilitates a self-directed approach to learning (Ungaretti et al, 2015; Ghufron \& Ermawati, 2018) with students working collaboratively towards a common learning outcome. Major \& Mulvihill (2018) suggests a paradigm shift to problem-based learning to provide teachers with the skills to implement this pedagogy in their classrooms. A similar shift in pedagogy is required in schools in England. The Department for 
Education for England (DFE, 2019, p 17) published an Initial Teacher Training core content framework that sets clear standards for all universities and training institutions in England on how to support trainee teachers. It states that trainee teachers should be given opportunities to:

discuss and analyze with expert colleagues how to plan lessons to promote collaboration, enabling critical thinking, problem-solving, and providing sufficient opportunity for pupils to consolidate and practice applying new knowledge and skills.

PBL utilizes problems as the means to promote new knowledge among students (Munawaroh, 2020). This involves, firstly, initiating ill-defined problems, then initiating a set of actions to solve them, whilst the teacher acts as a facilitator. This process promotes self-directed learning during problem-solving. However, self-directed learning and its impact on problem-solving have been contentiously debated, for example, Ghufron \& Ermawati (2018) argue that PBL can be confusing for some students as they may not be used to this type of learning. In contrast, Syarifudin et al. (2019) assert that this confusion enables students to pose questions to their peers so that collaborative activities can help in problem-solving, whilst the verbal interactions produced by students who have prior knowledge and experience can support others. However, students may become resistant to discard their alternative conceptions, thereby preventing them from accepting new scientific meanings different from theirs (Yuliati et al., 2018) if they are not supported in PBL. This creates cognitive dissonance, and the teacher needs to address this situation. Therefore, PBL is not about collecting facts but helping students to engage in inquiry processes, build and apply knowledge through collaborative learning, discuss ideas, elicit feedback, promote critical and creative thinking skills (Irwanto et al., 2018). This is corroborated by Vasconcelos (2012, p 229) who argues that "PBL is a process with learning and peer coaching potential that defines the challenge of learning and solving a problem as a feature of the proximal zone development". In the context of this study, the ill-defined problems provide opportunities for students to develop their knowledge by searching for information and applying prior knowledge, modeling and eliciting feedback, and collaboratively solving problems (Major \& Mulvihill, 2018; Syarifudin et al., 2019). This includes hypothesizing, analyzing questions, evaluating, reflecting, and making an informed argument about scientific concepts.

PBL is student-centered learning that embraces constructivism (Munawaroh, 2020) with teachers facilitating a collaborative learning environment (Irwanto et al., 2018; Mustofa \& Hidayah, 2020). This promotes problem-solving and helps students to optimize existing dissonance. Students are engaged in dialogue and interaction, asking questions, giving feedback, applying prior and acquired knowledge in developing their problemsolving skills (Irwanto et al., 2018; Zulkarnain et al., 2021). These processes of problem-solving are facilitated through a well-planned PBL by adopting the $3 \mathrm{C} 3 \mathrm{R}$ model that will be discussed in the next section. However, teachers' pedagogical knowledge may be a barrier in designing and implementing PBL and this can affect the problem-solving abilities of students. The barriers include good management, time 
involved in planning a PBL, confusion for some students (Ghufron \& Ermawati, 2018), creating a culture of collaboration, interdependence, and scaffolding students' learning. Poorly planned PBL problems may lead to misconceptions and anxieties in accomplishing the tasks. Wilder (2015, p. 430) asserts that:

lack of diversity regarding the subjects covered in $P B L$, poorly designed problems that do not cover all the skills required, and restricted studies in $P B L$ that have been confined to few countries have all been responsible for ineffective $P B L$.

Other limitations relate to the length of time in engaging students in PBL as longer-term may be more beneficial than shorter term. This is contrary to the views of Nisa et al. (2020) who argue that PBL is more effective than direct learning in improving problemsolving skills irrespective of the length of time. To highlight the inconsistencies in promoting problem-solving, the OECD (2014) reports that students in Singapore, Korea, and Japan, score higher in problem-solving than students in other countries such as the United Kingdom, where this study took place. This indicates the relevance of promoting PBL as a pedagogy of learning among science teachers and students. Loyens et al. (2015) suggest that PBL should be carried out on students of different ages and educational levels who have no previous experience of PBL to see if it would have similar academic gains to those of higher education students. Contrary, Wilder (2015) argues that rather than focusing on the attainment of students through PBL, a greater emphasis should center on the processes especially those problem-solving skills that led to the attainment.

\section{Approaches to designing PBL}

Different approaches to designing PBL have been suggested (see Barrows, 1986; Hung, 2009; OECD, 2014; Yew \& Goh, 2016). I will discuss three of them and consider a suitable one for this study. The first approach is proposed by Barrows (1986) and includes ten steps to PBL: encounter an ill-defined problem; have students ask questions about what is interesting, puzzling, or important to find out; pursue problem finding; map problem finding and prioritize a problem; investigate the problem; analyze results; reiterate learning; generate solutions and recommendations; communicate the results and conduct self-assessments. Secondly, the OECD's (2014 p31) Programme for International Student Assessment (PISA) PBL framework comprise of the following processes:

Nature of the problem situation: an interactive process with some information given to students while they explore the problem situation. Problem-solving process: this involves exploring and understanding the information provided with the problem, representing, and formulating by constructing graphical, tabular, symbolic, or verbal representations of the problem situation and formulating hypotheses about the relevant factors and relationships between them. Planning and executing: devising a plan by setting goals and sub-goals, and executing the sequential steps identified in the plan. Monitoring and reflecting: involves monitoring progress, reacting to feedback, and reflecting 
on the solution. Problem context: in what everyday scenario is the problem embedded such as social, personal, peers, family, and technology.

The third approach is Hung's (2009, p. 123) 3C3R model, a systematic conceptual framework that builds upon 9 steps PBL problem design processes:

Set goals and objectives; conduct content/task analysis; analyze context specification; select/generate PBL problem; conduct PBL problem affordance analysis; conduct correspondence analysis; conduct calibration processes; construct reflection component and examine inter-supporting relationships of 3 C3R components.

The $3 \mathrm{C}$ in the $3 \mathrm{C} 3 \mathrm{R}$ model represents the core components such as "content, context, and connection", whilst the $3 \mathrm{R}$ is the processing components "researching, reasoning and reflecting" (Hung, 2009, p. 122). The core components are concerned with structuring content knowledge, contextualizing domain knowledge, and building a conceptual framework around the topic under study (p. 122). It supports knowledge development and reasoning processes in problem-solving. The processing components aid in scientific inquiry and problem-solving processes. They direct students toward the intended learning outcome; adjust students' levels of cognitive readiness and address any worries they may experience with PBL. Exploring the PBL frameworks offer a better understanding of which instructional approach will support science teachers in planning PBL. This is because poorly planned PBL may lead to a lack of content knowledge of students (Hung, 2009; Yuliati et al., 2018), prevent the use of relevant resources, and affect the balance between teacher guidance and student independence. The frameworks discussed can support science teachers in designing PBL but in the context of this study, Hung's (2009) framework is sufficiently suitable in both design and implementation compared to the other frameworks as it accounts for content knowledge that is lacking in most frameworks. The 3C $3 \mathrm{R}$ model is facilitated using the 9 steps design process (appendix 1) and the links between them are discussed in the research section below. The 3C $3 \mathrm{R}$ model enhances the problem-solving ability of students however, Hung (2009) suggests further research is needed to validate this model. To ensure a balance between teacher-led and self-directed learning in problemsolving, a working guide (sets of instructions) on how teachers can facilitate the delivery of PBL is created. These instructions involve eliciting information from students, allowing them to ask questions, probe each other's views, direct, and lead their learning thereby discouraging teachers' dominance.

\section{METHOD}

This study is inspired by a constructivist approach to learning and data were collected through lesson observations, interviews, and focus groups.

\section{The research participants}

Fifty-two Key Stage 3 students in year 8 (13 years old) were involved in the study and this took 6 weeks (normal half-term in the school). The reasons for choosing the year 8 students are that they have no previous experience of PBL and the classes comprise of 
mixed ability students that serve as a representative sample of the cohort in year 8. Also, their teachers have no experience in designing and implementing PBL. The teachers have teaching experience of 7 and 13 years respectively. As both teachers and students lack knowledge of PBL, it may prevent any influence of external variables on the data collected. This purposive sampling (Gray, 2009) enables a detailed study in its entirety.

\section{The research}

This qualitative research took place in a co-education secondary school in England. The PBL problem was designed following a theoretical framework of the 3C3R model (Hung, 2009) and relies on the 9 steps in designing an effective PBL problem (see appendix 1). Steps 1 and 2 enable students to apply knowledge of the topic from the National curriculum in solving problems, developing content knowledge, and making connections to various concepts as part of the $3 \mathrm{C}$ components while the reasoning process links to the $3 \mathrm{R}$. Step 3 enables the analysis of the content covered in lesson and from students' research. It helps in developing content knowledge and connections between topics and promoting reasoning as part of the 3C3R components. Step 4 helps in developing the context of the problem to create further understanding as part of the $3 \mathrm{C}$ components. Steps 5 and 6 help in developing content and subject knowledge as part of the $3 \mathrm{C}$, and reasoning and reflecting in the $3 \mathrm{R}$ process. Steps 7 and 8 allow students to make connections on the various concepts and the content explored (3C) as well as promoting reasoning and reflection, 3R. Step 9 enables students to examine relationships between the different components of the 3C3R model. All these processes are required in problem-solving.

The PBL problems (appendix 1) apply to real-life situations and vary in terms of cognitive challenge to promote problem-solving, students' interest, and engagement. This forms the core knowledge aspect of PBL problems designated as $3 \mathrm{C}$ in the $3 \mathrm{C} 3 \mathrm{R}$ model. Hung (2009) argues that the core components of the $3 \mathrm{C} 3 \mathrm{R}$ model help to structure content knowledge, contextualize domain knowledge, and build a conceptual framework around any topic in this case Food and Nutrition. Following these steps will help to develop students' content knowledge, highlighted earlier as a major limitation in adopting PBL. The researcher met with the teachers and introduced them to PBL by discussing what it entails and answering any questions they had. The literature on PBL was given to them to develop theoretical knowledge of PBL processes. At the time of meeting with the teachers, the National curriculum topic for teaching was entitled Food and Nutrition, and this was used in creating PBL problems. At the subsequent meeting, the researcher provided training to the teachers on how to design and implement PBL problems following the 9 steps process (Hung, 2009). Working with the teachers was vital as it enabled them to become familiar with the processes of delivering a PBL by participating.

Students were presented with PBL problems and a set of criteria to achieve. An example of the problem is presented in appendix 1. There was flexibility in planning the illstructured PBL problems to aid students in applying prior knowledge and promoting a deeper understanding of scientific phenomena (Loyens et al., 2015). It enabled students 
to collaboratively identify the problems and engage in the inquiry or research processes, constructing knowledge, and giving feedback to peers. Students worked in groups of four while solving the problems (see appendix 1) by finding information from various means such as the internet, textbooks, homework feedback, science articles, and engaging in practical work and scientific investigations. They had the opportunity to create products and design experiments to meet the needs of related tasks, ask questions, and give feedback to their peers. This was facilitated by the teacher who gave support where needed. In a review of literature, Merritt et al. (2017) reported that the most effective studies on PBL involved problems, the use of small groups of students, and the student-centered iterative inquiry process. These have been adhered to in this study. Students collecting information formed the first processing component of $3 \mathrm{R}$ in the 3C3R model, that is, the researching phase. The second processing component is reasoning, and it allowed students to apply the knowledge gained from researching towards developing their problem-solving skills. They were analyzing information, generating, and testing hypotheses. The third processing component, reflecting, was crucial in helping them to optimize learning outcomes and promote problem-solving while the $3 \mathrm{C}$ helped in developing their content knowledge, context, and making connections to the problems being explored.

Each group of students collected information, discussed and evaluated their findings. They reflected on the findings before presenting to other students who in turn asked questions and gave feedback. These types of activities as corroborated by Irwanto et al. (2018) are effective in problem-solving while on the other hand, Merritt et al. (2017) stated that only a few studies in PBL gave opportunities for students to communicate findings to the whole class. While presenting their findings, students were reminded by their teachers to adhere to the working guide (a simple instruction to facilitate problemsolving) such as students taking turns in asking questions and giving feedback; probing each other's views; directing and leading their learning to support the articulation of ideas and promote inquiry. This enables problem-solving and co-constructing knowledge with the teachers. The working guide encourages teacher facilitation by delineating between students' self-directed learning and teacher support. The 9 steps process of designing a PBL is instrumental in structuring the core and processing components of 3C3R. For example, step 6 correspondence analysis, ensures that the contents of the PBL problems are within the cognitive domain of the students, as Hung (2009) advises that under or over affording PBL problems are likely to discourage students from problem-solving.

\section{Data collection}

Data were collected through lesson observations, interviews, and focus group discussions. Every week students attended four science lessons lasting 55 minutes each, for 6 weeks by engaging in the PBL problems earlier mentioned. Each week they attempted different problem-solving tasks covering the National curriculum contents required for the Food and Nutrition topic. Forty-eight lesson observations were carried out. The observations focused on how the teachers were implementing PBL in their classrooms to support learning. This was followed by a weekly meeting between the 
researcher and teachers to discuss progress, address any problems encountered when implementing PBL and provide further guidance and support. The interview was a semistructured one with sets of questions informed by outcomes from the lesson observations and meetings with the teachers. For example, the question 'what are the challenges you faced in delivering the PBL strategy in your classroom and how can these be improved?' sought the views of teachers on the effectiveness of implementing PBL as an instructional approach in learning and to identify areas for improvement. The focus group discussions with the teachers help in providing further evidence on attributes of learning that they may have observed among the students. It allowed the teachers to share their experience of engaging in the PBL and an opportunity for the researcher to clarify any terms or expressions used. The lessons, interviews, and focus group discussions were recorded in audio to capture every contribution made by the participants.

\section{Data analysis}

The recordings from lesson observations were transcribed and analyzed using thematic analysis (Braun \& Clarke, 2006). Recurrent themes were identified by following a process of coding to create relationships and links to the skills that may be promoted by PBL. Any technical terms used by the teachers were clarified during meetings as well as useful information from their lessons. This discussion formed part of the coding process and sharing the codes with them aided consistency. This helps in furthering the course of triangulation and ensures the validity and reliability of the data. Outcomes from the interviews and focus group discussions were also used as supporting evidence. This allowed for a careful and thorough interpretation of the teachers' experiences. The frequency of occurrence and percentage of each theme was calculated (Creswell, 2012) to give a distributional pattern and to identify which skill is promoted the most by PBL.

\section{FINDINGS}

Findings from the data collected were used to answer the research question: what problem-solving skills can science teachers promote and encourage among science students through designing and implementing PBL in their classrooms?

Three themes emerged, namely, the application of prior knowledge, collaborative learning, and modeling and eliciting feedback.

Table 1

The frequency of appearance of skills in PBL

\begin{tabular}{lll}
\hline Skills & $\mathrm{n}$ & $(\%)$ \\
\hline Application of prior knowledge & 62 & 28 \\
\hline Collaborative learning & 125 & 57 \\
\hline Modeling and eliciting feedback & 32 & 15 \\
\hline
\end{tabular}

\section{Application of prior knowledge}

The application of prior knowledge has a frequency score of $62(28 \%)$ (see table 1). Excerpts from lesson observations, interviews, and focus group discussions highlight aspects of applying prior knowledge, showing students' ability to contribute to problem- 
solving. This is supported by comments from a teacher interviewee who said that "some students were using the knowledge gained from other areas of their lives to answer questions and they were researching the tasks and coming up with their answers". Another teacher said that "all the students were very engaged with the activities, they were thinking and contributing ideas".

The excerpts from students' discussion below illustrate this:

Student 1 asked a question: "you said the male body needs more calories, but can you explain this to us?" Student 2 responded that "because men do a lot of exercises and use more energy in their work e.g., building”. While student 3 asked a further question: "if my body is used to being active, and later I become lazy the fat will build up in my body. This might become difficult to lose and may lead to obesity. So, what can I do?" Student 4 responded by saying that "liposuction helps suck the fat out of your body and can stop you from being obese" but student 5 added that "some people get a balloon put inside their stomach to minimize the food they eat, for the first three weeks they must take in liquid foods and porridge". The discourse shows that PBL problems enable students to apply prior knowledge when responding to and creating their questions. For example, students 4 and 5 suggest that liposuction and gastric balloon surgery can prevent obesity. The teacher interviewees consider the PBL activities aid the students in problem-solving with one of them saying that "engaging the students in PBL has created an environment where students are presenting the outcome from their findings and asking questions, engaging with new materials and creating knowledge on something they have never seen before". In support of this, a teacher from the focus group said that, "some had prior knowledge that is useful in the discussion, others were quite happy to read and find information out and tell others what pieces of information to add to their posters".

\section{Collaborative learning}

Collaborative learning has a frequency score of 125 (57\%) (table 1). Excerpts from lesson observations, interviews, and focus group discussions are presented below. Outcomes from the data show that the PBL problems engage students in creating new knowledge, sharing information, and critically analyzing other peoples' work as part of the problem-solving process. A teacher interviewee said:

the PBL project is different from other class activities as students were constantly processing information, sharing knowledge, and producing valuable learning materials, and questioning them through the process so that they can come up with possible solutions themselves.

While responding to the problem-solving tasks, students created various products such as a balanced diet for a 13-year-old, alongside posters and leaflets to guide the Mayor of London in educating people on the need for healthy eating and lifestyles. The teachers in the focus group said that "the students were sharing ideas, some agreed with each other's views while others did not and helped in developing them". In the same vein, a teacher interviewee said that "the students were engaged in high-order thinking by reviewing and validating their work, and this motivated others to learn". This is further 
illustrated by excerpts from lesson observations where student 1 said: "we included that information in the menu to promote awareness and to support people, but it can be changed". However, student 2 asserts that "I think we will need to justify this as we advise the mayor in our poster that obese people dislike themselves, cannot control their habit, lack self-esteem, confidence and are depressed". Also, student 3 said that "by creating this leaflet we can educate people and save the National Health Service from losing millions of pounds in treating lifestyle diseases that have become a problem in the UK". The discussion further illustrates evidence of peer support and problemsolving with students making sense of their work. This was re-affirmed by a teacher interviewee who said that

the activity allowed students to challenge each other in a way that enhances their thought processes whilst verifying the information and knowledge they were sharing. This allowed them to work together by supporting each other's learning and making meaning from it

\section{Modeling and eliciting feedback}

This has a frequency score of 32 (15\%) (table 1). By recalling the PBL problems on enzymes, the following excerpt reflects teacher-students interaction.

In response to a question, student 1 said that "enzyme, as shown in the poster, is a cutting machine that helps large molecules of food fit through the intestine". The teacher asks the students "are there any more suggestions on the role of enzymes or do you think he is correct?" The teacher then clarifies the role of enzymes by saying that "enzymes are specific, so carbohydrate enzymes will only breakdown carbohydrates. If food is not carbohydrate, what do you think would happen?". The teacher models feedback by saying that "enzymes are chemical substances produced in certain areas in the body and they help to speed up digestion". The teacher asks students to "explain what other roles the small intestine performs in the body". Student 2 response includes "small intestine also helps in the absorption of water"

The teacher's responses to students show the following: feedback to difficult questions that are above students' cognitive level, eliciting feedback, and corrective utterances to help students in using the right scientific terms. This is achieved by modeling feedback and clarifying misconceptions. These are useful in problem-solving processes. A teacher in the focus group asserts "I tell them do not remember the facts but remember the process that helps you get there". In support of this, a teacher interviewee said:

we need to open students' minds because in the wider world science can be an open subject and there is so much out there that they need to find out and we need to help them find the knowledge they may need for those questions they may get in their exams.

\section{DISCUSSION}

This research aims to answer the question: what problem-solving skills can science teachers promote and encourage among science students through designing and implementing PBL in their classrooms? The findings show that PBL promotes skills that 
contribute to problem-solving such as the application of prior knowledge, collaborative learning, and modeling and eliciting feedback (see figure 1). The three skills have various qualities that defined them, however, there are common qualities associated with these skills such as knowledge acquisition, creation, and transfer (K-ACT) concept; student feedback; critical thinking skills, and addressing misconceptions. Adopting the 3C3R model of PBL (Hung, 2009) following the 9 steps of designing PBL (appendix 1) has been responsible for developing these problem-solving skills among the students whilst responding to the ill-structured PBL problems. These provided students with the depth and breadth of knowledge and reasoning processes to solve problems collaboratively. Therefore, in the context of this study, it can be argued that these skills are responsible for promoting the problem-solving abilities of students. This is a view shared by Surur et al. (2020) who stated that PBL strategy has a significant influence on students' problem-solving abilities and this could be due to those accompanying skills. This gave the students an opportunity in constructing and using knowledge as a means of finding solutions to problems in a collaborative learning environment (Mustofa \& Hidayah, 2020).

Creating an opportunity for students to apply prior knowledge through PBL has been useful in promoting forms of cultural capital that contributed to their problem-solving abilities (figure 1). As they evaluated their learning, they contributed to developing the knowledge of other students. This was evidenced by the excerpts of their discussion and interviews with teachers that showed the students demonstrating varying levels of cognitive abilities. The teachers acknowledged that the students were processing information, sharing knowledge, and producing valuable learning material with solutions to the problems. This was facilitated by the 3C3R model as the core components, 3C, helped in structuring content knowledge, contextualizing domain knowledge, and building a conceptual framework around the problems presented. The $3 \mathrm{C}$ relates to steps $1,2,5$ and 6 of the 9 steps design process of PBL "set goals and objectives, conduct content and task analysis, and conduct PBL problem affordance analysis" respectively. This helped in developing students' content and subject knowledge. Therefore, allowing students to apply their prior knowledge to new and existing knowledge ultimately led to the problem-solving process (Zulkarnain et al., 2021). However, a strong attribute in applying prior knowledge as part of problem-solving (figure 1) is the fact that the PBL promoted scientific literacy and communication skills, student-generated inquiry, use of real-life situations, and applying cultural capital. The student-generated inquiry was instigated by the processing components (3R) researching, reasoning, and reflecting, and this enhanced problem-solving among the students. The $3 \mathrm{R}$ relates to steps 3,5 and 6 in the 9 steps design process such as "analyze context specification and conduct PBL problem affordance analysis". This helped to promote the research and problem-solving abilities of the students. Another feature includes critical thinking skills as it allowed the process of inquiry with students asking questions and finding solutions to the problems themselves, allowing them to address misconceptions and discard their alternative conceptions during problem-solving. This is corroborated by the teachers who said that the students were open to changes in their learning by engaging with new materials and creating knowledge. Another teacher said that some students had prior knowledge that 
allowed them to contribute to the problem-solving process and this resonates with the views of Loyens et al. (2015) that it will promote a deeper understanding of scientific phenomena.

Collaborative learning is informed by students' prior knowledge, and the ability to create products, work with others and find solutions to problems. The findings (figure 1) show qualities that contributed to collaborative learning such as creativity among students, scientific literacy, promoting curiosity, interactive and dialogic learning, leadership, social capital, and sequencing learning with shared responsibility. The $3 \mathrm{C} 3 \mathrm{R}$ model promoted collaborative problem-solving by adopting a constructivist approach with the students evaluating outcomes from their work, peer assessing, and supporting each other. The model directed students toward the intended learning outcomes (see appendix 1) and the cognitive demands of PBL. Hence, students were able to reflect on their experiences and contribute to the learning of others as expressed in the K-ACT concept (figure 1). The 3C3R model relates to steps 1, 3, 4, 5/6, 7/8 of the 9 steps design process of PBL problems (appendix 1) such as "set goals and objectives, analyze context specification, select/generate PBL problems, conduct PBL problem affordance analysis, and conduct calibration processes" respectively. This enabled students to develop content and subject knowledge by researching, reasoning, and reflecting on their outcome following the ill-structured problems (appendix 1). A strong aspect of this is the ability for them to evaluate their learning and at the same time reflect on areas requiring improvement by expressing their developing knowledge through class interactions, sharing of ideas, and analyzing their state of knowledge. An important attribute identified in collaborative problem-solving is that the students developed critical thinking skills promoted through the $3 \mathrm{C} 3 \mathrm{R}$ model which were useful in evaluating their learning. Therefore, engaging students in PBL embraced a holistic approach to learning as it promoted collaborative problem solving (Trevor et al., 2020; Yew \& Goh, 2016) whilst developing the soft skills required in solving real-world problems (Mustofa \& Hidayah, 2020).

The PBL activities created an opportunity for modeling and eliciting feedback, a skill that should be developed among science students to support problem-solving ability. Modeling and eliciting feedback promoted student-teacher and peer interactions and problem-solving. As with the other skills, it also contributed to the K-ACT concept (figure 1). Nevertheless, the pedagogical implication in this feedback process is that teachers do not correct students' misconceptions during problem-solving but facilitates a collaborative learning environment with students as assessors and self-regulators. The students are given opportunities to develop their problem-solving skills by asking and analyzing questions, finding information, developing their knowledge, and evaluating their learning. This process is supported by Irwanto et al. (2018) as forming part of an inquiry that enables critical thinking and solving unstructured problems. The teachers insist on students using the right scientific terms in communicating their ideas and this helps in developing scientific knowledge and creates an impact on the nature of science skills (Moutinhoa et al., 2015). It helps students to redefine their constructs in alignment with that of the teacher by identifying gaps in their prior and current knowledge and developing problem-solving skills. Unfortunately, most science lessons may not develop 
students' skills in modeling and eliciting feedback because they are teacher-led, therefore it requires a shift in teachers' pedagogy to align with the purpose of PBL. Adopting the $3 \mathrm{C} 3 \mathrm{R}$ model of PBL creates a balance between teacher guidance and student independence by promoting problem-solving and this is facilitated through steps $1,4,5 / 6,7 / 8$, and 9 of the 9 steps design of PBL (see appendix 1).

The data presented (table 1) shows that collaborative learning is the most dominant skill promoted by science teachers implementing PBL in their classrooms. This does not imply that other skills mentioned or not considered may not promote problem-solving. The question revolves around how PBL can be utilized effectively by science teachers to support problem-solving among students. The answer lies in developing teachers' pedagogical knowledge in designing and implementing PBL. Following the 9 steps in planning PBL has been useful in validating the 3C3R model of problem-solving and enhancing teachers' pedagogical knowledge. However, some of the steps were modified to meet the intended learning outcomes and support problem-solving. For example, steps 5 and 6 were merged as "conduct PBL problem affordance analysis" (see appendix 1). This took into considerations that subject-specific planning may vary. An (2013) shares similar views that although following the 9 steps helps in designing PBL problems, a slight modification is necessary to support novice teachers in adopting it. However, creating a working guide earlier mentioned (sets of instructions) for the teachers and students during PBL helps to implement and facilitate problem-solving. It acts as a deterrent from becoming a teacher-led problem-solving task by promoting all the skills listed. Also, lesson planning involving PBL requires expertise and resources which can be time-consuming, thereby hindering teachers from engaging with it. Teachers should be encouraged to maximize learning especially the time students spend in the researching phase of the $3 \mathrm{C} 3 \mathrm{R}$ model, thereby suggesting further research into exploring a blended PBL in the secondary science classroom would be useful. 


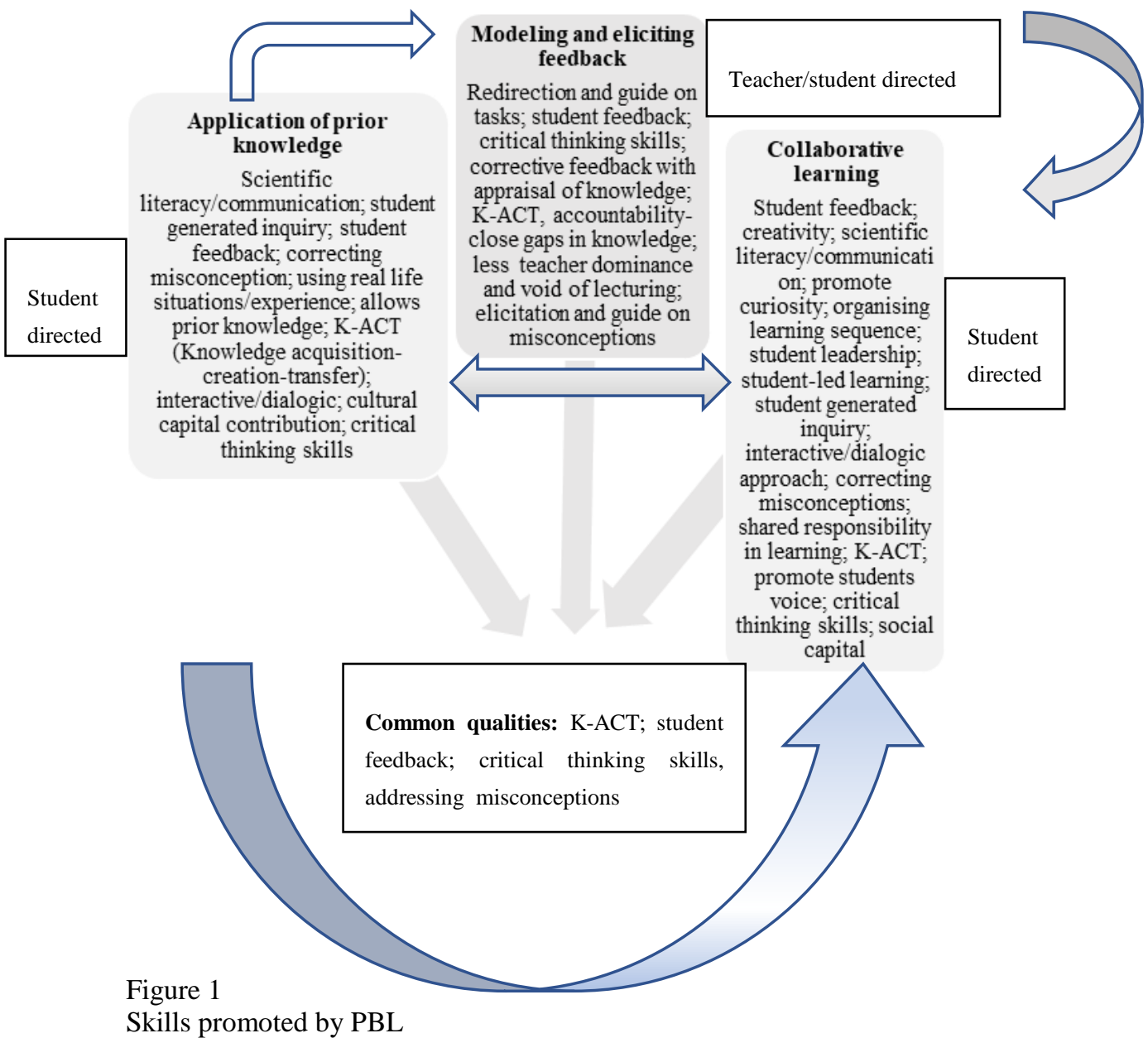

Skills promoted by PBL

\section{CONCLUSION}

Evidence from this study shows that PBL develops problem-solving skills among science students such as the application of prior knowledge, collaborative learning, and modeling and eliciting feedback. Collaborative learning is considered the dominant skill required in problem-solving, however, all these skills share similar qualities such as the $\mathrm{K}$-ACT concept. The three skills can be encouraged and promoted by science teachers through designing and implementing PBL activities to support students in problemsolving. This can be achieved by adopting the 3C3R model and following the 9 steps design of PBL problems. Therefore, there is a need to promote teachers' pedagogy and support them in planning and implementing PBL as this study has found this to be an area for development among the teachers involved. 


\section{LIMITATIONS}

A limitation of this study is the lack of performance data to ascertain the impact of PBL on students' attainment in problem-solving. However, various studies have focused on this aspect but with less emphasis on those skills promoting problem-solving. Concrete evidence emerged from the lesson observations, interviews, and focus groups that are sufficient in answering the research question. Notwithstanding, a further layer of data could be collected by interviewing students to seek their perceptions of engaging in PBL and what experiences if any, could be shared to improve approaches and accessibility to designing a PBL. The duration of the study was six weeks. It could, however, have gone on for a longer period as more benefits may be realized in PBL in the long term.

\section{REFERENCES}

An, Y. (2013). Systematic design of blended PBL: exploring the design experiences and support needs of PBL novices in an online environment, Contemporary Issues in Technology and Teacher Education, 13(1), 61-79.

Barrows, H. S. (1986). A taxonomy of problem-based learning methods. Medical Education 20(6), 481-486.

Braun, V., \& Clarke, V. (2006) Using thematic analysis in psychology, Qualitative Research in Psychology, 3(2), 77-101.

Creswell, J. W. (2012). Educational research. Planning, conducting, and evaluating quantitative and qualitative research ( $4^{\text {th }} \mathrm{ed}$.). Boston: Pearson Education, Inc.

Department for Education, DFE, (2019). Initial teacher training core content framework. Retrieved on 27 July 2020 from:

https://www.gov.uk/government/publications/initial-teacher-training-itt-core-contentframework

Ertmer, P. A., \& Simons, K. D. (2006). Jumping the PBL implementation hurdle: supporting the efforts of K-12 teachers, The Interdisciplinary Journal of Problem based Learning 1(1), 40-54.

Ghufron, M. A., \& Ermawati, S. (2018). The strengths and weaknesses of cooperative learning and problem-based learning in EFL writing class: teachers and students' perspectives. International Journal of Instruction, 11(4), 657-672

Gray, D., E. (2009) Doing research in the real world (2nd ed.). London: Sage

Hung, W. (2009). The 9-step problem design process for problem-based learning: application of the 3C3R model. Educational Research Review 4(2), 118-141.

Irwanto, Saputro, A. D., Rohaeti, E., \& Prodjosantoso, A. K. (2018). Promoting critical thinking and problem-solving skills of preservice elementary teachers through processoriented guided-inquiry learning (POGIL). International Journal of Instruction, 11(4), 777-794. 
Loyens, S. M. M., Jones, S. H., Mikkers, J., \& van Gog, T. (2015). Problem-based learning as a facilitator of conceptual change, Learning and Instruction 38, 34-42

Major, T., \& Mulvihill, T. M. Dr. (2018). Problem-based learning pedagogies in teacher education: the case of Botswana. Interdisciplinary Journal of Problem-Based Learning, $12(1)$.

Merritt, J., Lee, M., Rillero, P., \& Kinach, B. M. (2017). Problem-based learning in K-8 mathematics and science education: a literature review. Interdisciplinary Journal of Problem-Based Learning, 11(2).

Moutinhoa, S., Torresa, J., Fernandesa, I., \& Vasconcelos, C. (2015). Problem-based learning and nature of science: a study with science teachers. Procedia - Social and Behavioral Sciences 191, 1871-1875 Retrieved on 20 June 2020 from: https://core.ac.uk/download/pdf/82086075.pdf

Munawaroh. (2020). The influence of problem-based learning model as learning method, and learning motivation on entrepreneurial attitude, International Journal of Instruction, 13(2), 431-444.

Mustofa, R. F., \& Hidayah, Y. (2020). The effect of problem-based learning on lateral thinking skills. International Journal of Instruction, 13(1), 463-474.

Nisa, A. R., Asrowi \& Murwaningsih, T. (2020). The effectiveness of value clarification technique (VCT) and problem-based learning (PBL) models on social problem-solving skills viewed from emotional intelligence, Elementary Education Online, 19 (3), 17511767.

Nurkhin, A., Kardoyo, K., Pramusinto, H., Setiyani, R. \& Widhiastuti, R. (2020). Applying blended problem-based learning to accounting studies in higher education; optimizing the utilization of social media for learning, International Journal of Emerging Technologies in Learning, 15(8), 22-39.

OECD (Organisation for Economic Cooperation and Development) (2014). PISA 2012 results: creative problem solving: students' skills in tackling real-life problems, Volume V, PISA, OECD Publishing. Retrieved on March 23, 2019 from:http://dx.doi.org/10.1787/9789264208070-en

Surur, M., Degeng, I. N. S, Setyosari, P. \& Kuswand, D. (2020). The effect of problembased learning strategies and cognitive styles on junior high school students' problemsolving abilities, International Journal of Instruction, 13(4), 35-48

Syarifudin, Purwanto, Irawan, E. B., Sulandra, I. M., \& Fikriyah, U. (2019). Student verbal interaction in geometry problem-solving through cognitive activities. International Journal of Instruction, 12(3), 167-182

Trevor, K. E., Gregory, L. N., \& Sean, P. S (2020). Using collaborative learning to develop students' soft skills, Journal of Education for Business, 95(2), 106-114 
Ungaretti, T., Thompson, K. R., Miller, A., \& Peterson, T. O (2015). Problem-based learning: lessons from medical education and challenges for management education, Academy of Management Learning \& Education, 14(2), 173-186.

Vasconcelos, C. (2012). Teaching environmental education through PBL: evaluation of a teaching intervention program, Res Sci Educ, 42, 219-232.

Wilder, S. (2015). Impact of problem-based learning on academic achievement in high school: a systematic review. Educational Review 67(4), 414-435

Yew, E. H. J., \& Goh, K. (2016). Problem-based learning: an overview of its process and impact on learning, Health Professions Education 2, 75-79

Yuliati, L., Riantoni, C. \& Mufti, N. (2018). Problem-solving skills on direct current electricity through inquiry-based learning with PhET simulations. International Journal of Instruction, 11(4), 123-138.

Zulkarnain, Zulnaidi, H., Heleni, S., \& Syafri, M. (2021). Effects of SSCS teaching model on students' mathematical problem-solving ability and self-efficacy. International Journal of Instruction, 14(1), 475-488

\section{Appendix 1: Problem based learning.}

The problem solving is based on the Food and Nutrition topic. Steps 1-9 are the 9 steps process of designing PBL problems (Hung, 2009).

Learning objectives: to explain the roles of different food nutrients in the body and justify their rationale for inclusion in a healthy diet.

Statement of the problem: What is in our food?

\section{The 9 steps design process of PBL}

Step 1: Set goals and objectives: the students will apply knowledge of food contents in the National curriculum to solve real-life problems.

Step 2: Conduct content/task analysis: lessons introducing the concepts of food and nutrition contents as stipulated in the National curriculum. Topics include food groups and their sources and uses, balanced diet, food pyramid, healthy living, digestion, and digestive system, enzyme action, chemical tests for the major nutrients in food.

Step 3: Analyze context specification: this creates a research opportunity and makes students aware of relevant learning materials. Useful resources include the internet, textbooks, outcome from practical work and scientific investigations (such as energy in food substances, food tests, and digestion process), homework feedback, science articles and magazines, relevant science posters in classrooms, and applying prior knowledge.

Step 4: Select/generate PBL problem:

Given the extended reports from Government, the media, and healthy eating experts, there have been concerns in the quality of nutritional value of food that students eat within and outside school. This poor diet has been reported as affecting students' health and learning. You have been 
recruited as a nutritionist or an expert to help students decide on a healthy and balanced diet required for good health. How would you solve this problem?

Context of the problem: The students you will be helping are from one of the most deprived boroughs in London and most of them are on free school meals (FSM). This meant that they rely on free lunch given to them during the school day. On returning home after school, their parents could only afford to give them fast food for dinner rather than a home-cooked meal despite knowing that fast foods may be unhealthy. How would you help the students to eat healthily?

Steps 5 and 6: Conduct PBL problem affordance analysis:

Students work in groups to understand the problems and problem-solving processes and develop the domain knowledge required to solve the problems. The questions below will help them to achieve this process:

List the 7 groups of foods and state two examples of foods that belong to each group.

State the functions of the 7 groups of foods.

Discuss in your groups and reflect on what you have done by revisiting the problem in step 4 and from all the information gathered, identify any learning gaps, and suggest solutions to the problems highlighted and how you would advise students to live a healthy lifestyle.

State any problems that may result from not eating certain nutrients in your food.

How would you describe a balanced diet?

Create a menu of a balanced diet for a 13-year-old to include breakfast, lunch, and dinner.

Explain the reasons for your choices.

What would you consider a healthy diet? State reasons

Describe the nutritional information on your poster.

Explain why people like to know how many calories are in their food. Use the food labels to guide you.

Add other information that you have not considered above and from your prior knowledge and experience. Justify the rationale for choices made and what new information can you contribute to your work?

Steps 7 and 8: Conduct calibration processes:

Refer to the problem highlighted in step 4 and the guide in steps $5 / 6$. What are the outcomes? Allow students in groups to discuss outcomes from their findings to aid reflection before presenting to the whole class who in turn ask questions and give feedback. The process is monitored and directed by the students.

Step 9: Examine inter-supporting relationships of 3C3R components.

Students can examine relationships between the different components of the $3 \mathrm{C} 3 \mathrm{R}$ model during the question and feedback sessions and reflect on the group work and presentations. 